Article

\title{
Study on Absorption Mechanism and Tissue Distribution of Fucoidan
}

\author{
Xu Bai ${ }^{1,+}$, E Zhang ${ }^{1,+}$, Bo Hu ${ }^{1}$, Hao Liang ${ }^{1}$, Shuliang Song ${ }^{1, *}$ and Aiguo Ji 1,2,* \\ 1 Marine College, Shandong University, Weihai 264209, China; 15634407267@163.com (X.B.); \\ Ezhang815@126.com (E.Z.); hobophar@163.com (B.H.); lianghao@sdu.edu.cn (H.L.) \\ 2 School of Pharmaceutical Sciences, Shandong University, Jinan 250012, China \\ * Correspondence: songshuliang@sdu.edu.cn (S.S.); jiaiguo@sdu.edu.cn (A.J.) \\ + These authors have contributed equally.
}

Received: 27 January 2020; Accepted: 25 February 2020; Published: 28 February 2020

check for updates

\begin{abstract}
Fucoidan exhibits several pharmacological activities and is characterized by high safety and the absence of toxic side effects. However, the absorption of fucoidan is not well-characterized. In the present study, fucoidan were labeled with fluorescein isothiocyanate (FITC) and their ability to traverse a monolayer of Caco-2 cells was examined. The apparent permeability coefficients $\left(\right.$ Papp $\left.\times 10^{-6}\right)$ of FITC-labeled fucoidan (FITC-fucoidan) were 26.23, 20.15, 17.93, $16.11 \mathrm{~cm} / \mathrm{sec}$, respectively, at the concentration of $10 \mu \mathrm{g} / \mathrm{mL}$ at $0.5,1,1.5$ and $2 \mathrm{~h}$. The absorption of FITC-fucoidan was suppressed by inhibitors of clathrin-mediated endocytosis, chlorpromazine, $\mathrm{NH}_{4} \mathrm{Cl}$, and Dynasore; the inhibition rates were $84.24 \%, 74.61 \%$, and $63.94 \%$, respectively. This finding suggested that clathrin-mediated endocytosis was involved in fucoidan transport. Finally, tissue distribution of FITC-fucoidan was studied in vivo after injection of $50 \mathrm{mg} / \mathrm{kg}$ body weight into the tail vein of mice. The results showed that FITC-fucoidan targeted kidney and liver, reaching concentrations of 1092.31 and $284.27 \mu \mathrm{g} / \mathrm{g}$ respectively after $0.5 \mathrm{~h}$. In summary, the present work identified the mechanism of absorption of fucoidan and documented its tissue distribution, providing a theoretical basis for the future development of fucoidan applications.
\end{abstract}

Keywords: fucoidan; fluorescent labeling; clathrin; absorption; tissue distribution.

\section{Introduction}

Fucoidan is a water-soluble heteropolysaccharide, derived mostly from brown algae, such as Fucus vesiculosus (Figure 1) [1] and certain echinoderms [2,3]. The structure of fucoidan varies among species, whose skeleton mostly contains sulfate substituents and pyranose or other glycosyl unit, but the main structural unit consists of sulfated L-fucose [4]. As a naturally occurring chemical, the distribution of its relative molecular mass ranges from 1 to $1000 \mathrm{kDa}$ [5]. The $\mathrm{SO} 4^{2-}$ is the main functional group responsible for the biological properties of polysaccharides, and its quantity and position are critical determinants of the activity of these macromolecules. Recent studies have shown that fucoidan can exert a wide range of pharmacological effects, including anti-inflammatory [6], antitumor [7], antioxidative [8], antiviral, and antithrombotic activity, as well as improving immune response and lipid metabolism [5,9-12]. However, only a small number of studies addressed the mechanism of absorption and tissue distribution of this compound in vivo given their high molecular size [13-16]. Therefore, a detailed knowledge of its absorption mechanism is important for its biological activities. 


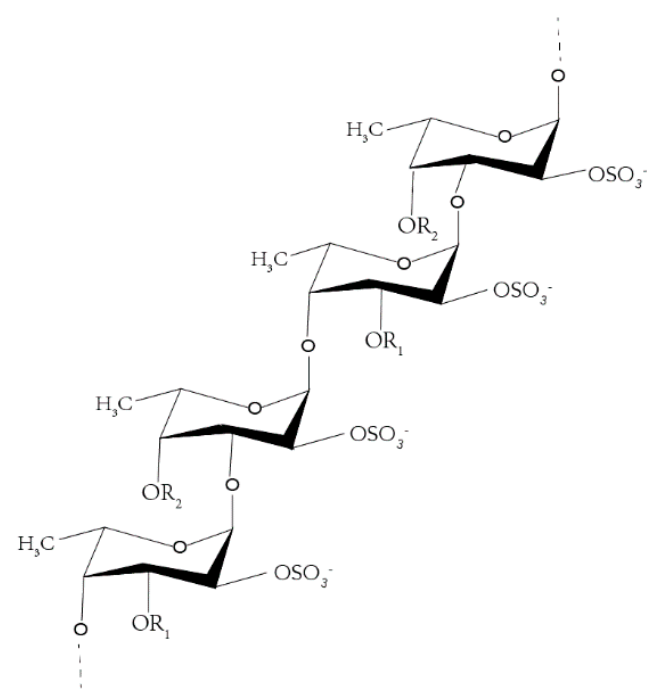

Figure 1. Fucoidan structure from Fucus vesiculosus.

Given the complex chemical structure of fucoidan, the difficulty of the mechanism of absorption determination has impeded the development of research on intestinal absorption of this molecule. Recently, techniques based on the detection of fluorescence have been employed in drug microanalysis because of their specificity, sensitivity, and low detection threshold [17]. Although fucoidan lacks chromogenic groups, fluorescent reagents can bind to the hemiacetal aldehyde group at the end of the polysaccharide molecule and generate a fluorescent moiety capable of absorbing ultraviolet light under certain conditions. The objective of the current study was to optimize the method of fluorescent labeling of fucoidan by fluorescein isothiocyanate (FITC) [18] and elucidate the mechanism of fucoidan absorption utilizing the Caco-2 cell 7-day model.

Although it is known that the tissue distribution of polysaccharides depends largely on their type and physicochemical properties [19-21], studies on this subject are limited. Therefore, the understanding of the mechanism of absorption and pharmacokinetics of fucoidan will not only promote the high-value development of kelp resources but will also provide the theoretical foundation for the application of fucoidan in healthcare products and pharmaceuticals.

\section{Results}

\subsection{Fluorescence Labeling of Fucoidan}

The results of the photography under the gel imager showed that FITC-fucoidan had been marked successfully (Figure 2). Fucoidan had been successfully labeled. Specifically, the fucose content of fucoidan and FITC-fucoidan was $42.86 \%$ and $45.11 \%$, respectively (Table 1), indicating that the method of FITC labeling did not affect the fucose content in fucoidan.

Table 1. The fucose content and sulfate content of fucoidan before and after being labeled.

\begin{tabular}{ccc}
\hline \multirow{2}{*}{ Fucoidan } & \multicolumn{2}{c}{ Content \% } \\
\cline { 2 - 3 } & Before Labeled & After Labeled \\
\hline Fucose content & $42.86 \pm 0.24$ & $45.11 \pm 0.88$ \\
Sulfate content & $25.37 \pm 0.25$ & $25.33 \pm 0.34$ \\
\hline
\end{tabular}




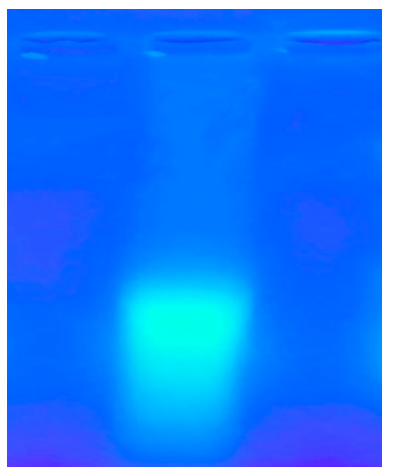

Figure 2. Agarose electrophoresis of fluorescein isothiocyanate-fucoidan (FITC-fucoidan).

\subsection{Establishment and Assessment of Seven-Day Absorption Model of Caco-2 Cells}

The transmembrane resistance (TEER) values of the monolayer of Caco-2 cells at different plating densities were tested (Figure 3A), showing that either too high or too low cell density was not conducive to the formation of the cell monolayer. At the appropriate cell density, the formation of monolayers can be accelerated in a short time by adding puromycin (PM). Therefore, Caco- 2 cells were cultured in Puromycin -Dulbecco's modified Eagle's medium (PM-DMEM) at a density of $10 \times 10^{4}$ cells/well for 7 days [22]. Together, the monolayers of Caco-2 cells cultured in PM-DMEM medium were compact and intact for 7 days, which had no significant difference from the 21-day model and could be used for drug absorption study (Figure 3B).

(A)

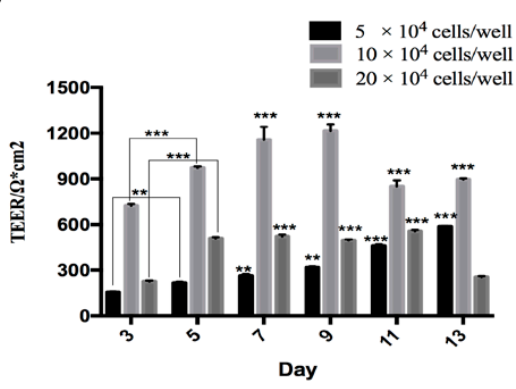

(C)

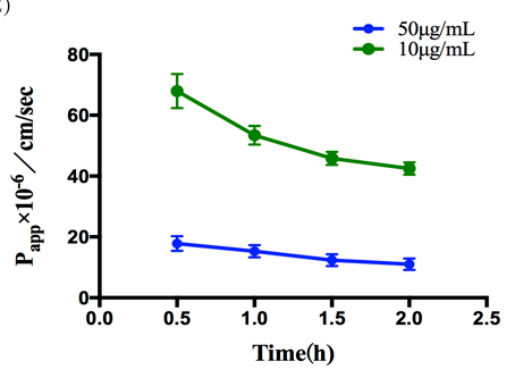

(B)

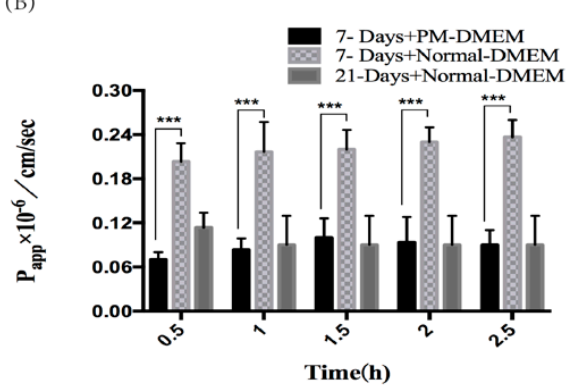

(D)

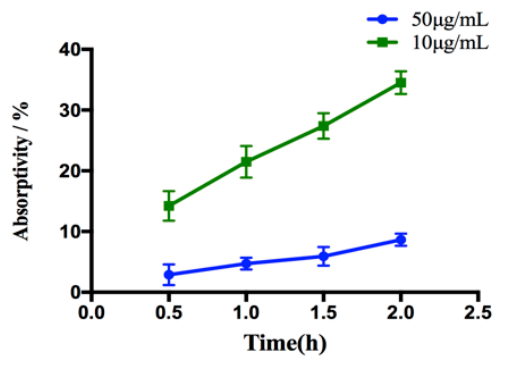

Figure 3. Establishment and assessment of seven-day absorption model of Caco-2 cells. (A) The transmembrane resistance (TEER) comparison at different concentration of Caco-2 cell density which were cultured in Puromycin -Dulbecco's modified Eagle's medium (PM-DMEM) medium. (B) The $\mathrm{P}_{\text {app }}$ of the markers of paracellular transport was expressed as the means $\pm \operatorname{SD}(n=3)$. (C) The Papp of FITC-transferrin at different time and concentration was expressed as the means $\pm \operatorname{SD}(n=3)$. (D) The absorptivity of FITC-transferrin at different time and concentration was expressed as the means $\pm \operatorname{SD}(n=3)$.

\subsection{Verification of the Absorption and Transport Function of Caco-2 Monolayer Cell Model}

FITC-Transferrin is often used to test the function of Caco-2 monolayer cell model and it was transported from upper chamber to the lower chamber, which can be concluded that the 7-day absorption model of Caco- 2 cells had been successfully established and exhibited adequate absorption 
and transport characteristics. At different concentration and time, the Papp and absorptivity of FITC-Transferrin with $10 \mu \mathrm{g} / \mathrm{mL}$ were higher than those of FITC-Transferrin with $50 \mu \mathrm{g} / \mathrm{mL}$, and the lower the concentration, the easier it was to be absorbed (Figure 3C,D). So, it was speculated that the absorption and transport of transferrin was saturated.

\subsection{The Mechanism of Fucoidan Absorption and Transport}

\subsubsection{Absorption and Transport of Fucoidan}

FITC-fucoidan did not affect the proliferation of the cells at concentrations of up to $1000 \mu \mathrm{g} / \mathrm{mL}$, indicating the absence of a toxic effect. The Papp and absorption rates of FITC-fucoidan showed a trend consistent with the values obtained for FITC-transferrin, they decreased with increasing concentration (Figure 4A,B). These findings suggested that the transport of fucoidan may be carrier-dependent since transferrin is often used as a marker for clathrin-mediated endocytosis [23,24].

(A)

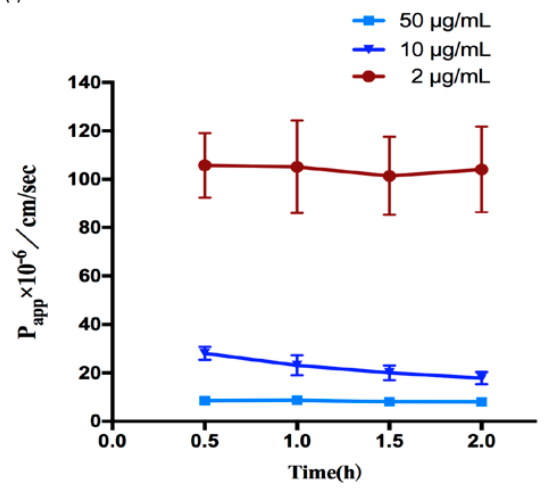

(C)

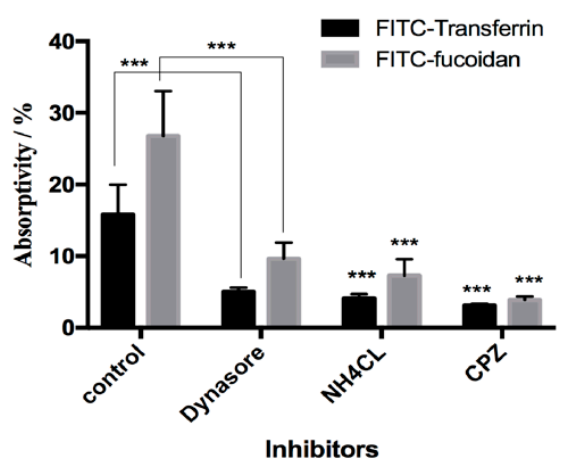

(B)

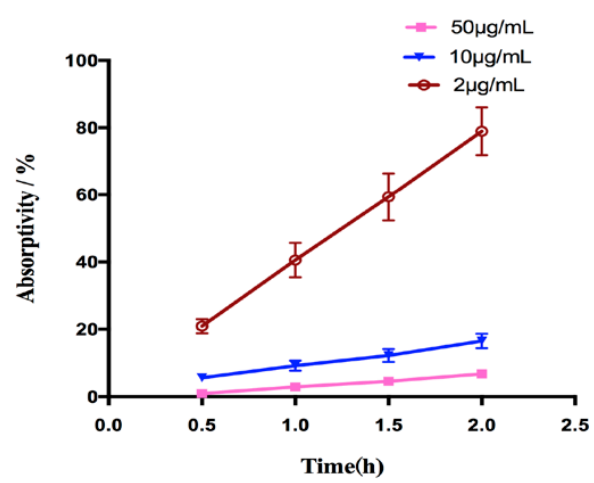

(D)

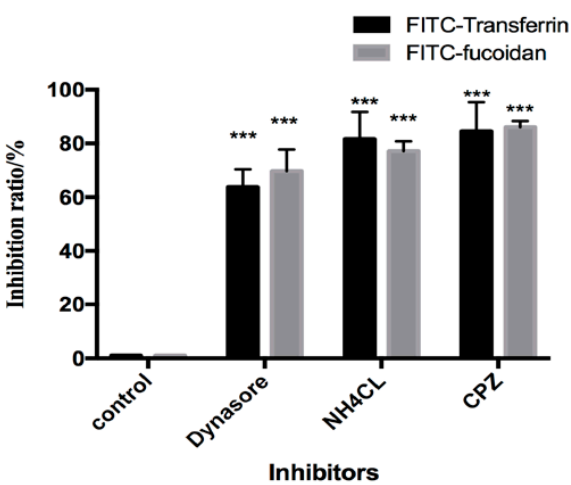

Figure 4. The absorption of FITC-fucoidan and the effect of inhibitors on it. (A) The Papp of FITC-fucoidan at different time and concentration was expressed as the means $\pm \operatorname{SD}(n=3)$. (B) The absorptivity of FITC-fucoidan at different time and concentration was expressed as the means \pm SD $(n=3)$. (C) The absorptivity of FITC-transferrin and FITC-fucoidan by adding clathrin inhibitors $\mathrm{CPZ}$, Dynasore and $\mathrm{NH}_{4} \mathrm{CL}$ was expressed as the means $\pm \mathrm{SD}(n=3)$. (D) The inhibition rate of FITC-Transferrin and FITC-fucoidan by adding clathrin inhibitors $\mathrm{CPZ}$, Dynasore and $\mathrm{NH}_{4} \mathrm{CL}$ was expressed as the means $\pm \operatorname{SD}(n=3)$.

\subsubsection{Effect of Inhibition of Clathrin-Mediated Endocytosis on the Absorption and Transport of Fucoidan}

Similar to FITC-Transferrin, Chlorpromazine (CPZ), Dynasore and $\mathrm{NH}_{4} \mathrm{CL}$ can inhibit FITC-fucoidan absorption. Compared with the control group, Papp values of Dynasore group, $\mathrm{NH}_{4} \mathrm{CL}$ group and $\mathrm{CPZ}$ group were $8.07,5.68$ and $3.53 \mathrm{~cm} / \mathrm{sec}$ respectively, the absorption rate were $4.88 \%, 2.08 \%$, and $2.13 \%$, respectively (Figure $4 \mathrm{C}, \mathrm{D}$ ). CPZ, Dynasore and $\mathrm{NH}_{4} \mathrm{CL}$ are inhibitors of clathrin, thus, inhibitors of clathrin-mediated endocytosis reduced the absorption of FITC-fucoidan, demonstrating the involvement of the clathrin endocytic pathway in the absorption and transport of fucoidan. 


\subsection{Tissue Distribution of Fucoidan in Mice}

\subsubsection{Toxicity of Fucoidan in Mice}

During the observation period, the mice's eating, drinking and excretion activities were normal, and the mice's weight gain had no significant difference. The doses of FITC-fucoidan ranging from 10 to $2500 \mathrm{mg} / \mathrm{kg}$ body weight did not cause any mortality, and all mice survived the observation period, indicating the safety of FITC-fucoidan. Post-mortem examination showed that the morphology and color of all organs were normal, and no other pathological changes were found, providing additional documentation of FITC-fucoidan safety.

\subsubsection{Tissue Distribution of Fucoidan}

It has been confirmed that free FITC did not affect the detection of FITC-fucoidan in biological samples. The standard curve of FITC-fucoidan in various tissues was tested (Table 2). The concentrations of FITC-fucoidan in various tissue samples at different times (Figure 5A-E) and the main pharmacokinetic parameters of FITC-fucoidan ( $50 \mathrm{mg} / \mathrm{kg}$ ) after tail vein injection in mice were tested (Table 3$)$. These results documented that FITC-fucoidan was rapidly eliminated from the blood after intravenous administration; the blood concentration of FITC-fucoidan reached $66.37 \mu \mathrm{g} / \mathrm{g}$ after $30 \mathrm{~min}$ and decreased afterward; FITC-fucoidan was not detected in the blood after $4 \mathrm{~h}$. The presence of FITC-fucoidan was identified in the liver, spleen, lung, and kidney, with the latter always exhibiting the highest concentration. The level of FITC-fucoidan in the kidney tissue reached $1092.31 \mu \mathrm{g} / \mathrm{g}$ after $4 \mathrm{~h}$, followed by a decrease in concentration, indicating that the kidney has a strong ability to uptake FITC-fucoidan. The concentration of FITC-fucoidan in the liver reached a maximum of $284.27 \mu \mathrm{g} / \mathrm{g}$ at $0.5 \mathrm{~h}$, and in the lung a maximum of $110.92 \mu \mathrm{g} / \mathrm{g}$ at $4 \mathrm{~h}$. FITC-fucoidan was always detected in the spleen, and the concentration reached a maximum of $77.79 \mu \mathrm{g} / \mathrm{g}$ at $6 \mathrm{~h}$. The molecule was not detected in the brain and the heart.

(A)

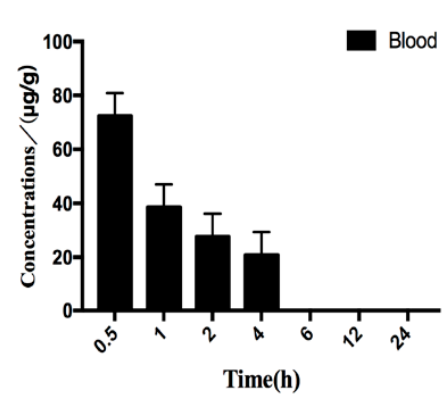

(D)
(B)

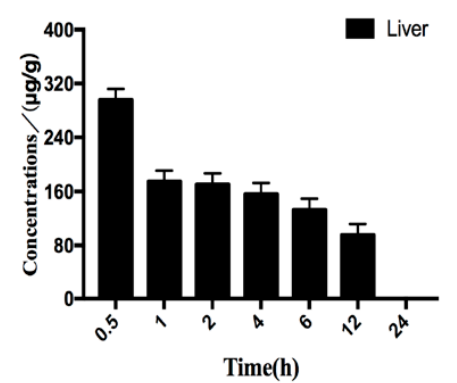

(C)

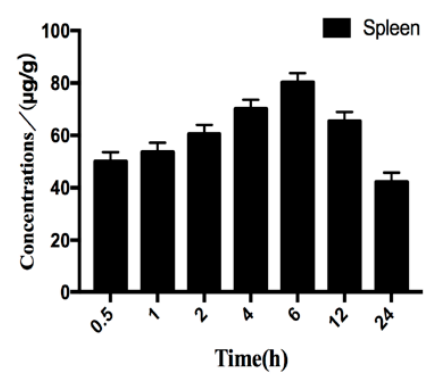

(E)
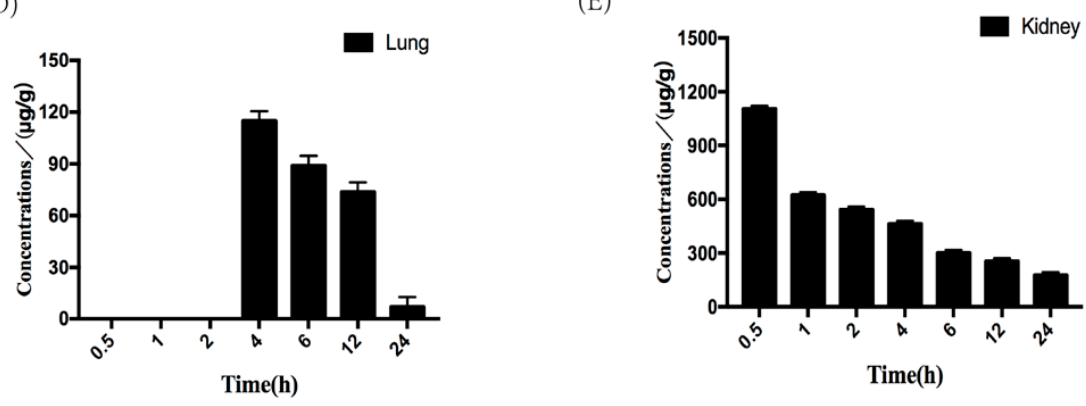

Figure 5. Tissue distribution of FITC-fucoidan in mice. (A) Concentrations of FITC-fucoidan in blood $(\mu \mathrm{g} / \mathrm{g})$ was expressed as the means $\pm \mathrm{SD}(n=5)$. (B) Concentrations of FITC-fucoidan in liver $(\mu \mathrm{g} / \mathrm{g})$ was expressed as the means $\pm \mathrm{SD}(n=5)$. (C) Concentrations of FITC-fucoidan in spleen $(\mu \mathrm{g} / \mathrm{g})$ was expressed as the means $\pm \operatorname{SD}(n=5)$. (D) Concentrations of FITC-fucoidan in lung $(\mu \mathrm{g} / \mathrm{g})$ was expressed as the means $\pm \mathrm{SD}(n=5)$. (E) Concentrations of FITC-fucoidan in kidney $(\mu \mathrm{g} / \mathrm{g})$ was expressed as the means $\pm \mathrm{SD}(n=5)$. 
Table 2. The standard curve of FITC-fucoidan in tissues.

\begin{tabular}{ccc}
\hline Tissue & Standard Curve & $\mathbf{R}^{\mathbf{2}}$ \\
\hline Blood & $\mathrm{Y}=1028.62 \mathrm{X}+48217.63$ & 0.999 \\
Heart & $\mathrm{Y}=1595.96 \mathrm{X}+153165.43$ & 0.994 \\
Liver & $\mathrm{Y}=3217.36 \mathrm{X}+164583.03$ & 0.998 \\
Spleen & $\mathrm{Y}=2902.54 \mathrm{X}+26586.43$ & 0.998 \\
Pulmonary & $\mathrm{Y}=3194.69 \mathrm{X}+35547.02$ & 0.995 \\
Renal & $\mathrm{Y}=1791.22 \mathrm{X}+215822.65$ & 0.99 \\
Brain & $\mathrm{Y}=2427.88 \mathrm{X}+48044.49$ & 0.998 \\
\hline
\end{tabular}

Table 3. Main pharmacokinetic parameters of FITC-fucoidan in mice tissues by intravenous administration $(50 \mathrm{mg} / \mathrm{kg})$.

\begin{tabular}{ccccccc}
\hline \multirow{2}{*}{ Parameter } & Unit & \multicolumn{5}{c}{ Tissue } \\
\cline { 3 - 6 } & & Blood & Liver & Spleen & Lung & Kidney \\
\cline { 3 - 7 } $\mathrm{K}_{\mathrm{el}}$ & $1 / \mathrm{h}$ & $0.25 \pm 0.10$ & $0.07 \pm 0.01$ & $0.003 \pm 0.02$ & $0.18 \pm 0.05$ & $0.03 \pm 0.04$ \\
$\mathrm{~T}_{1 / 2}$ & $\mathrm{~h}$ & $2.77 \pm 0.82$ & $10.67 \pm 3.73$ & $209.22 \pm 6.94$ & $3.79 \pm 0.97$ & $22.27 \pm 1.75$ \\
$\mathrm{~T}_{\max }$ & $\mathrm{h}$ & 0.5 & $0.5 \pm 0.29$ & $6 \pm 1.15$ & $4 \pm 1$ & 0.5 \\
$\mathrm{C}_{\max }$ & $\mu \mathrm{g} / \mathrm{g}$ & $66.37 \pm 25.56$ & $284.27 \pm 211.88$ & $77.79 \pm 30.05$ & $110.92 \pm 81.897$ & $1092.31 \pm 297.66$ \\
$\mathrm{C}_{0}$ & $\mu \mathrm{g} / \mathrm{g}$ & $135.28 \pm 59.91$ & $495.25 \pm 159.14$ & $47.61 \pm 17.28$ & $188.58 \pm 48.32$ & $1949.94 \pm 1448.45$ \\
$\mathrm{AUC}_{0-\mathrm{t}}$ & $\mu \mathrm{g} / \mathrm{g} \times \mathrm{h}$ & $138.71 \pm 20.64$ & $1653.86 \pm 567.04$ & $1597.28 \pm 394.38$ & $1694.21 \pm 580.70$ & $7520.11 \pm 2110.44$ \\
$\mathrm{AUC}_{0-\infty}$ & $\mu \mathrm{g} / \mathrm{g} \times \mathrm{h}$ & $198.11 \pm 41.10$ & $2947.506 \pm 992.52$ & $22886.97 \pm 1301.13$ & $1709.85 \pm 588.22$ & $12834.30 \pm 5247.13$ \\
$\mathrm{MRT}_{0-\infty}$ & $\mathrm{h}$ & $3.23 \pm 1.30$ & $14.66 \pm 5.94$ & $303.96 \pm 13.44$ & $6.88 \pm 0.37$ & $28.14 \pm 12.324$ \\
$\mathrm{CL}$ & $(\mathrm{mg}) /(\mu \mathrm{g} / \mathrm{g}) / \mathrm{h}$ & $0.25 \pm 0.04$ & $0.02 \pm 0.001$ & $0.002 \pm 0.01$ & $0.03 \pm 0.004$ & $0.004 \pm 0.003$ \\
\hline
\end{tabular}

\section{Materials and Methods}

\subsection{Materials}

Fucoidan from F. vesiculosus was purchased from Sigma-Aldrich, USA ( $\geq 95 \%$, CAS:9072-19-9), its monosaccharide composition has been detected (fucose:138.7 \pm 5.5; rhamnose: $2.0 \pm 0.6$; galactose: $27.9 \pm 1.4$; glucose: $2.5 \pm 1.8$; xylose: $12.8 \pm 1$, 6 ; mannose: $0.2 \pm 0.4$ : glucuronic acid: $18.5 \pm 1.9)[25,26]$; Caco-2 cell was purchased from Kunming Institute of Zoology, Chinese Academy of Sciences Kunming Cell Bank; Trypsin was purchased from Invitrogen, US; Penicillin and Streptomycin was purchased from Invitrogen, USA; Chromatographic column (G4000PWXL) was purchased from Agilent, USA; Methylthiazolyldiphenyl-tetrazolium bromide (MTT) was purchased from Beyotime Biotechnology, China; DMSO was purchased from Sigma-Aldrich, USA; puromycin was purchased from Aladdin, China; fluorescent yellow was purchased from Aladdin, China; chlorpromazine hydrochloride was purchased from Aladdin, China; Dynasore was purchased from Aladdin, China; Ammonium chloride was purchased from Shanghai Sinopharm Group, China; FITC labeled human transferrin (Chromatographic grade) was purchased from Jackson, USA; Fluorescein isothiocyanate (FITC) was purchased from Aladdin, China; Sodium cyanoborohydride was purchased from Aladdin, China; Fucose was purchased from L-Fucose, Aladdin, China; Transwell Chamber $(0.4 \mu \mathrm{m})$ was purchased from Millipore, USA.

\subsection{Fluorescent Labeling of Fucoidan}

After dissolving $1 \mathrm{~g}$ of fucoidan in phosphate buffer solution ( $\mathrm{pH} 7.4)$, tyramine $(2 \mathrm{~g})$ was added and the reaction was carried out at $37^{\circ} \mathrm{C}$ for $24 \mathrm{~h}$. Subsequently, $\mathrm{NaBH}_{3} \mathrm{CN}(1 \mathrm{~g})$ was added, the sample was placed in a shaker at $37^{\circ} \mathrm{C}$ for $96 \mathrm{~h}$, and then centrifuged to obtain a supernatant. The FITC-labeled fucoidan (FITC-fucoidan) solution was obtained by reacting the supernatant with $25 \mathrm{mg}$ FITC at $37^{\circ} \mathrm{C}$ for $36 \mathrm{~h}$. The resulting solution was centrifuged, and the supernatant was subjected to ultrafiltration using a tangential flow membrane filtration system (Spectrum Laboratories, Inc, USA). Small molecules were removed by Superdex 30 (Thermo Fisher Scientific) and the preparation was freeze-dried to obtain pure FITC-fucoidan [25]. 


\subsection{Effect of FITC Labeling on the Content of Fucose and Sulfate}

Using fucoidan and FITC-fucoidan as samples to be tested, the changes of fucose content and sulfate content in fucoidan were determined by cysteine hydrochloride method and barium chloride-gelatin method respectively $[27,28]$.

\subsection{MTT Assay for Cell Viability}

The cytotoxicity of FITC-fucoidan to Caco-2 cells was determined using the MTT assay. Precultured cells $\left(5 \times 10^{4}\right.$ cells/well) in DMEM medium were plated on a 96-well microplate for $24 \mathrm{~h}$. Subsequently, the medium was removed and replaced with medium containing different concentrations of FITC-fucoidan $(0,10,100,1000 \mu \mathrm{g} / \mathrm{mL})$. After incubation for $48 \mathrm{~h}, 10 \mu \mathrm{L}$ of $5 \mathrm{mg} / \mathrm{mL}$ MTT solution was added to each well, and the cells were incubated for an additional $4 \mathrm{~h}$. The medium was aspirated, $100 \mu \mathrm{L}$ of DMSO was added to each well, and the plates were shaken for 3 min using a vortex instrument until thoroughly mixed. The absorbance of each well was measured at a wavelength of $490 \mathrm{~nm}$ by a microplate reader [28].

\subsection{Caco-2 Cell Culture and Establishment of Caco-2 Monolayer Cell Model}

Caco-2 cells were cultured in DMEM containing 20\% (v/v) FBS, penicillin and streptomycin $(100 \mathrm{U} / \mathrm{mL})$, and the cells were cultured in a $25 \mathrm{~cm}^{2}$ cassette culture flask and placed in a $\mathrm{CO}_{2}$ incubator (Thermo Electron Corporation, USA). When the cell density reached $80-90 \%$ confluence, it was digested with $0.25 \%$ trypsin- $0.02 \%$ Ethylene Diamine Tetraacetic Acid (EDTA) and passaged at a ratio of 1:3. Cells in the logarithmic phase of growth were suspended at concentrations of $25 \times 10^{4}, 50 \times 10^{4}$, and $100 \times 10^{4}$ cells/mL in DMEM containing $0.4 \mu \mathrm{g} / \mathrm{mL}$ puromycin $(\mathrm{PM})$. The cells in PM-DMEM were cultured for 7 days, and the cells in normal-DMEM for 21 days. Add $1.0 \mathrm{~mL}$ of medium to the lower chamber of Transwell. The liquid was changed every other day [29].

After the cells were cultured for 21 days in normal-DMEM and 7 days in PM-DMEM, a Caco-2 cell monolayer model was formed by using a Millicell-ERS voltammeter (Millipore Company, USA) to monitor the transmembrane resistance (TEER) of the Caco- 2 cell monolayer film in real time to evaluate the quality of the monolayer cell membrane. The TEER value of the Caco-2 cell monolayers exceeding $>500 \Omega \times \mathrm{cm}^{2}$ was considered to be qualified for subsequent transmembrane transport experiments. After modeling, $250 \mu \mathrm{g} / \mathrm{mL}$ fluorescent yellow solution was added to the apical side to detect the transmittance of basal side fluorescent yellow at different times. The fluorescence intensity of the medium was measured by a microplate reader at $490 \mathrm{~nm}$ and at $520 \mathrm{~nm}$.

\subsection{Verification of the Absorption and Transport Function of Caco-2 Monolayer Cell Model}

After a seven-day absorption model of Caco-2 cells was established, $300 \mu \mathrm{L}$ of FITC-labeled transferrin (FITC-transferrin) solution $(10$ or $50 \mu \mathrm{g} / \mathrm{mL})$ was added to the upper chamber, and $800 \mu \mathrm{L}$ of DMEM medium was added to the lower chamber. The chambers were incubated at $37^{\circ} \mathrm{C}$, and the medium from the lower chamber was collected at 30, 60, 90, 120, and $150 \mathrm{~min}$. The fluorescence intensity of the medium was measured by a microplate reader at $490 \mathrm{~nm}$ and at $520 \mathrm{~nm}$ [29].

\subsection{The Mechanism of Fucoidan Absorption and Transport}

After establishing a 7-day absorption model of Caco-2 cells in a transwell chamber, $300 \mu \mathrm{L}$ of FITC-fucoidan solution, at concentrations of 2,10, and $50 \mu \mathrm{g} / \mathrm{mL}$, was added to the upper chamber, and $800 \mu \mathrm{L}$ of DMEM medium was added to the lower chamber. The chambers were incubated at $37^{\circ} \mathrm{C}$, and the medium from the lower chamber was collected at 30, 60, 90, 120, and $150 \mathrm{~min}$. The intensity of fluorescence was measured by a microplate reader at $490 \mathrm{~nm}$ and $520 \mathrm{~nm}$.

The cell monolayers were incubated with solution containing different inhibitors (CPZ, Dynasore, and $\mathrm{NH}_{4} \mathrm{Cl}$ in DMEM medium at concentrations of 10, 20, and $50 \mu \mathrm{g} / \mathrm{mL}$ ). The experiments included two groups, the first group is as follows: blank group, FITC-fucoidan group, CPZ + 
FITC-fucoidan group, $\mathrm{NH}_{4} \mathrm{Cl}+$ FITC-fucoidan group, Dynasore+FITC-fucoidan group; the second group is as follows: FITC-transferrin group, $\mathrm{CPZ}+$ FITC-transferrin group, $\mathrm{NH}_{4} \mathrm{Cl}+$ FITC-transferrin group, Dynasore+FITC-transferrin group. Inhibitors were added to the upper chamber respectively, and DMEM medium was added to the lower chamber. After $30 \mathrm{~min}$, the medium in the upper chamber was aspirated, and $10 \mu \mathrm{g} / \mathrm{mL}$ of FITC-fucoidan or FITC-transferrin solutions were added to the upper chamber. DMEM medium was added to the lower chamber and the culture was incubated at $37^{\circ} \mathrm{C}$ for $120 \mathrm{~min}$. Finally the medium from the lower chamber was collected at 30,60, and $120 \mathrm{~min}$. The intensity of fluorescence was measured by a microplate reader at $490 \mathrm{~nm}$ and $520 \mathrm{~nm}$.

\subsection{Tissue distribution of Fucoidan in Mice}

Twenty Kunming mice were kept under a 12-h light-dark cycle at $22 \pm 2{ }^{\circ} \mathrm{C}$ and humidity of $60 \pm 10 \%$; water and food were available ad libitum. Mice were fasted overnight before the experiment. The mice were weighed and randomly divided into 4 groups, the blank group was injected with normal saline, and the three remaining groups were injected into the tail vein with 10, 500, and $2500 \mathrm{mg} / \mathrm{kg}$ FITC-fucoidan for 7 days, respectively. The weight was measured again at the end of the experiment to determine the toxicity of fucoidan on mice.

The untreated mice were sacrificed, a standard curve was established as the following method. Blood was quickly collected from the heart, centrifuged in a tube containing $0.2 \mathrm{~mL}$ of $4 \%$ trisodium citrate, and the supernatant plasma was aspirated and frozen. Heart, liver, spleen, lung, kidney, and brain tissue were collected and homogenized. Tissue homogenate and plasma were added with 0 , $0.2,0.4,0.8,1,2,4,6,8,10,15,20,25,30,35,40,45,50,60,80$ and $100 \mu \mathrm{L}$ of FITC solutions respectively to obtain FITC-tissue homogenate mixture. The fluorescence intensity was measured at $490 \mathrm{~nm}$ and $520 \mathrm{~nm}$ using a microplate reader.

The treated mice was injected into the tail vein with a solution of FITC-fucoidanl (50 mg/kg). The blank group received an injection of normal saline. Mice were sacrificed at $0.5,1,2,4,6,12$, and $24 \mathrm{~h}$ after administration of FITC-fucoidan. All tissues and organs were collected and homogenized according to the same method as above. The intensity of fluorescence was measured at $490 \mathrm{~nm}$ and $520 \mathrm{~nm}$ using a microplate reader. PK Solver 2.0 and non-atrioventricular model were used to analyze the pharmacokinetic parameters of the experiment [30,31].

\subsection{Statistical Analysis}

All data in graphs were presented as the mean value \pm standard deviation from three independent measurements. The statistical analysis was used in statistical software (SPSS 21.0.0.0, Chicago, Ill, USA) and GraphPad Prism 7.00 (GraphPad Software, California, USA). $P<0.05$ was considered significant.

\section{Conclusions}

In recent years, much has been learned about the biological activities of fucoidan. However, previous studies on the mechanism of polysaccharide transport in the intestine have focused on oligosaccharide and high molecular weight polysaccharides was less successful. The molecular mechanisms that allow high molecular weight polysaccharides to cross the intestinal epithelial cell monolayers are critical for its clinical application. In this study, we found that absorption of fucoidan was negatively correlated with its concentration before reaching dynamic equilibrium. It is speculated that the absorption and transport of fucoidan need carriers and the endocytosis pathway of reticulin is involved in their absorption. With the further development of the experiment, the tissue distribution of fucoidan in mice was explored. The experimental results showed that fucoidan rapidly distributed from blood to tissues, and accumulated preferentially to kidney and liver, but it was not detected in the heart and brain tissues in this experiment, which can provide a theoretical basis for the future development of fucoidan applications. 
In order to explain the absorption mechanism of fucoidan more clearly, more in-depth studies on gene and protein levels are needed in the future to lay a deeper theoretical foundation for the development of fucoidan.

Author Contributions: X.B. designed the project, performed data analysis, and wrote the paper. E.Z. performed data analysis, and B.H. contributed to the paper writing. H.L. contributed to data processing. S.S. and A.J. guided the experiment. All authors have read and agreed to the published version of the manuscript.

Funding: This research received no external funding.

Acknowledgments: This work was supported by the Shandong Provincial Nature Science Foundation, China (ZR2017MH040).

Conflicts of Interest: The authors declare no conflict of interest.

\section{References}

1. Cao, H.T.T.; Mikkelsen, M.D.; Lezyk, M.J.; Bui, L.M.; Tran, V.T.T.; Silchenko, A.S.; Kusaykin, M.I.; Pharm, T.D.; Truong, B.H.; Holck, J.; et al. Novel Enzyme Actions for Sulphated Galactofucan Depolymerisation and a New Engineering Strategy for Molecular Stabilisation of Fucoidan Degrading Enzymes. Mar. Drugs 2018, 16, E422. [CrossRef] [PubMed]

2. Wang, J.; Zhang, Q.; Zhang, Z.; Zhang, H.; Niu, X. Structural studies on a novel fucogalactan sulfate extracted from the brown seaweed Laminaria japonica. Int. J. Biol. Macromol. 2010, 47, 126-131. [CrossRef] [PubMed]

3. Anastyuk, S.D.; Imbs, T.I.; Shevchenko, N.M.; Dmitrenok, N.M.; Zvyagintseva, T.N. ESIMS analysis of fucoidan preparations from Costaria costata, extracted from alga at different life-stages. Carbohydr. Polym. 2012, 90, 993-1002. [CrossRef] [PubMed]

4. Usoltseva, R.V.; Shevchenko, N.M.; Malyarenko, O.S.; Ishina, I.A.; Ivannikova, S.I.; Ermakova, S.P. Structure and anticancer activity of native and modified polysaccharides from brown alga Dictyota dichotoma. Carbohydr. Polym. 2018, 180, 21-28. [CrossRef] [PubMed]

5. Lee, S.H.; Ko, C.I.; Jee, Y.; Jeong, Y.; Kim, M.; Kim, J.S.; Jeon, Y.J. Anti-inflammatory effect of fucoidan extracted from Ecklonia cava in zebrafish model. Carbohydr. Polym. 2013, 92, 84-89.

6. Cumashi, A.; Ushakova, N.A.; Preobrazhenskaya, M.E.; D’Incecco, A.; Piccoli, A.; Totani, L.; Tinari, N.; Morozevich, G.E.; Berman, A.E.; Bilan, M.I.; et al. Interuniversitario Nazionale per la Bio-Oncologia, A comparative study of the anti-inflammatory, anticoagulant, antiangiogenic, and antiadhesive activities of nine different fucoidans from brown seaweeds. Glycobiology 2007, 17, 541-552. [CrossRef]

7. Chen, M.C.; Hsu, W.L.; Hwang, P.A.; Chou, T.C. Low Molecular Weight Fucoidan Inhibits Tumor Angiogenesis through Downregulation of HIF-1/VEGF Signaling under Hypoxia. Mar. Drugs 2015, 13, 4436-4451. [CrossRef]

8. Wei, H.; Gao, Z.; Zheng, L.; Zhang, C.; Liu, Z.; Yang, Y.; Teng, H.; Hou, L.; Yin, Y.; Zou, X. Protective Effects of Fucoidan on Abeta25-35 and d-Gal-Induced Neurotoxicity in PC12 Cells and d-Gal-Induced Cognitive Dysfunction in Mice. Mar. Drugs 2017, 15, E77. [CrossRef]

9. Wijesinghe, W.A.; Jeon, Y.J. Exploiting biological activities of brown seaweed Ecklonia cava for potential industrial applications: A review. Int. J. Food Sci. Nutr. 2012, 63, 225-235. [CrossRef]

10. Kim, S.K.; Pangestuti, R. Biological activities and potential health benefits of fucoxanthin derived from marine brown algae. Adv. Food Nutr. Res. 2011, 64, 11-28.

11. Mathew, L.; Burney, M.; Gaikwad, A.; Nyshadham, P.; Nugent, E.K.; Gonzalez, A.; Smith, J.A. Preclinical Evaluation of Safety of Fucoidan Extracts From Undaria pinnatifida and Fucus vesiculosus for Use in Cancer Treatment. Integr. Cancer Ther. 2017, 16, 572-584. [CrossRef] [PubMed]

12. Sae-Lao, T.; Luplertlop, N.; Janvilisri, T.; Tohtong, R.; Bates, D.O.; Wongprasert, K. Sulfated galactans from the red seaweed Gracilaria fisheri exerts anti-migration effect on cholangiocarcinoma cells. Phytomedicine 2017, 36, 59-67. [CrossRef] [PubMed]

13. Zhang, E.; Chu, F.; Xu, L.; Liang, H.; Song, S.; Ji, A. Use of fluorescein isothiocyanate isomer I to study the mechanism of intestinal absorption of fucoidan sulfate in vivo and in vitro. Biopharm. Drug Dispos. 2018, 39, 298-307. [CrossRef] [PubMed]

14. Chen, G.; Xie, M.; Wan, P.; Chen, D.; Ye, H.; Chen, L.; Zeng, X.; Liu, Z. Digestion under saliva, simulated gastric and small intestinal conditions and fermentation in vitro by human intestinal microbiota of polysaccharides from Fuzhuan brick tea. Food Chem. 2018, 244, 331-339. [CrossRef] [PubMed] 
15. Wang, Z.; Zhang, H.; Shen, Y.; Zhao, X.; Wang, X.; Wang, J.; Fan, K.; Zhan, X. Characterization of a novel polysaccharide from Ganoderma lucidum and its absorption mechanism in Caco-2 cells and mice model. Int. J. Biol. Macromol. 2018, 118, 320-326. [CrossRef] [PubMed]

16. Wang, K.; Cheng, F.; Pan, X.; Zhou, T.; Liu, X.; Zheng, Z.; Luo, L.; Zhang, Y. Investigation of the transport and absorption of Angelica sinensis polysaccharide through gastrointestinal tract both in vitro and in vivo. Drug Deliv. 2017, 24, 1360-1371. [CrossRef]

17. Azhdarinia, A.; Ghosh, P.; Ghosh, S.; Wilganowski, N.; Sevick-Muraca, E.M. Dual-labeling strategies for nuclear and fluorescence molecular imaging: A review and analysis. Mol. Imaging Biol. 2012, 14, 261-276. [CrossRef]

18. Ticha, M.; Kocourek, J. Fluorescein-labeled O-glycosyloxyalkenyl-aminoalkenyl-acrylamide copolymers in lectin-saccharide binding studies. Carbohydr. Res. 1991, 213, 339-343. [CrossRef]

19. Zhao, X.; Guo, F.; Hu, J.; Zhang, L.; Xue, C.; Zhang, Z.; Li, B. Antithrombotic activity of oral administered low molecular weight fucoidan from Laminaria Japonica. Thromb. Res. 2016, 144, 46-52. [CrossRef]

20. Lin, X.; Wang, Z.; Sun, G.; Shen, L.; Xu, D.; Feng, Y. A sensitive and specific HPGPC-FD method for the study of pharmacokinetics and tissue distribution of Radix Ophiopogonis polysaccharide in rats. Biomed. Chromatogr. 2010, 24, 820-825. [CrossRef]

21. Yu, M.; Wang, Y.; Ma, F.; Yu, W.; Jiang, T.; Lv, Z. Pharmacokinetics, Tissue Distribution and Excretion Study of Fluoresceinlabeled PS916 in Rats. Curr. Pharm. Biotechnol. 2017, 18, 391-399.

22. Sevin, E.; Dehouck, L.; Costa, A.F.A.; Cecchelli, R.; Dehouck, M.P.; Lundquist, S.; Culot, M. Accelerated Caco-2 cell permeability model for drug discovery. J. Pharmacol. Toxicol. Methods 2013, 68, 334-339. [CrossRef] [PubMed]

23. Wang, K.; Wu, J.; Cheng, F.; Huang, X.; Zeng, F.; Zhang, Y. Acidic Polysaccharide from Angelica sinensis Reverses Anemia of Chronic Disease Involving the Suppression of Inflammatory Hepcidin and NF-kappaB Activation. Oxid. Med. Cell Longev. 2017, 2017, 7601592. [CrossRef] [PubMed]

24. Zhu, Z.; Zhu, B.; Ai, C.; Lu, J.; Wu, S.; Liu, Y.; Wang, L.; Yang, J.; Song, S.; Liu, X. Development and application of a HPLC-MS/MS method for quantitation of fucosylated chondroitin sulfate and fucoidan in sea cucumbers. Carbohydr. Res. 2018, 466, 11-17. [CrossRef]

25. Ale, M.T.; Maruyama, H.; Tamauchi, H.; Mikkelsen, J.D.; Meyer, A.S. Fucoidan from Sargassum sp. and Fucus vesiculosus reduces cell viability of lung carcinoma and melanoma cells in vitro and activates natural killer cells in mice in vivo. Int. J. Biol. Macromol. 2011, 49, 331-336. [CrossRef]

26. Oliveira, C.; Granja, S.; Neves, N.M.; Reis, R.L.; Baltazar, F.; Silva, T.H.; Martins, A. Fucoidan from Fucus vesiculosus inhibits new blood vessel formation and breast tumor growth in vivo. Carbohydr. Polym. 2019, 223, 115034. [CrossRef]

27. Wang, C.Y.; Wu, T.C.; Hsieh, S.L.; Tsai, Y.H.; Yeh, C.W.; Huang, C.Y. Antioxidant activity and growth inhibition of human colon cancer cells by crude and purified fucoidan preparations extracted from Sargassum cristaefolium. J. Food Drug Anal. 2015, 23, 766-777. [CrossRef]

28. Lim, S.J.; Aida, W.M.W.; Schiehser, S.; Rosenau, T.; Bohmdorfer, S. Structural elucidation of fucoidan from Cladosiphon okamuranus (Okinawa mozuku). Food Chem. 2019, 272, 222-226. [CrossRef]

29. Martirosyan, A.; Grintzalis, K.; Polet, M.; Laloux, L.; Schneider, Y.J. Tuning the inflammatory response to silver nanoparticles via quercetin in Caco-2 (co-)cultures as model of the human intestinal mucosa. Toxicol. Lett. 2016, 253, 36-45. [CrossRef]

30. Lin, A.; Su, X.; She, D.; Qiu, K.; He, Q.; Liu, Y. LC-MS/MS determination and comparative pharmacokinetics of strychnine, brucine and their metabolites in rat plasma after intragastric administration of each monomer and the total alkaloids from Semen Strychni. J. Chromatogr. B Analyt. Technol. Biomed. Life Sci. 2016, 1008, 65-73. [CrossRef]

31. Kim, O.K.; Nam, D.E.; Lee, M.; Kwon, H.O.; Park, J.; You, Y.; Kim, S.I.; Lee, J.; Jun, W. The Effects of Costaria costata Extracts on Atopic Dermatitis in an In Vitro Model. J. Med. Food 2016, 19, 945-951. [CrossRef] [PubMed]

Sample Availability: Samples of the fucoidan are available from the authors.

(C) 2020 by the authors. Licensee MDPI, Basel, Switzerland. This article is an open access article distributed under the terms and conditions of the Creative Commons Attribution (CC BY) license (http://creativecommons.org/licenses/by/4.0/). 